\title{
ВНЕШНИЕ УСЛОВИЯ И ФАКТОРЫ ФУНКЦИОНИРОВАНИЯ ОТРАСЛЕЙ ЖИВОТНОВОДСТВА РЕСПУБЛИКИ БЕЛАРУСЬ
}

\author{
Н.В. Киреенко, А.В. Горбатовский, О.Н. Горбатовская, Л.И. Довнар
}

Проведена оценка условий и факторов внешней экономической среды функционирования основных отраслей животноводства в новых условиях хозяйствования. С позиции импортоемкости и конкурентоспособности продукции проанализировано состояние отрасли по отдельным видам ее производственных ресурсов, таких как корма, ветеринарные препараты и племенной скот. Определен уровень производства продукции животноводства в государствах - членах Евразийского экономического союза. Оценены конкурентные преимущества соответствующих отраслей Беларуси в условиях функционирования ЕАЭС по цене товаропроизводителей, уровню продуктивности сельскохозяйственных животных, рентабельности производства. Выявлены значимые внешние факторы, обусловливающие современный вектор развития животноводства в контексте реализации комплекса мер по обеспечению продовольственной безопасности, импортозамещению и развитию экспорта в условиях усиления конкуренции на рынке государств - членов ЕАЭС.

Ключевые слова: сельское хозяйство, животноводство, кормопроизводство, конкурентоспособность, Евразийский экономический союз.

JEL-классификация: Q10, Q11, Q12, Q17, Q18.

DOI: $10.46782 / 1818-4510-2020-2-96-108$

Материал поступил 16.03.2020 2.

Современное социально-экономическое развитие Республики Беларусь в условиях динамичности внешних факторов ориентировано на рост эффективности функционирования национального агропромышленного комплекса и составляющих его продуктовых подкомплексов. Участие страны в международной и региональной экономической интеграции отражается на финансовой устойчивости отечественных товаропроизводителей, обусловливает ее зависимость от конъюнктуры мирового рынка и требует соблюдения установленных критериев конкурентоспособности и качества производимой сельскохозяйственной продукции и продуктов питания.
Теоретические и прикладные проблемы обеспечения эффективности функционирования аграрной сферы в контексте наращивания экспортного потенциала, сбалансированного развития внешней торговли агропродовольственными товарами, прогнозирования и своевременного принятия мер, направленных на минимизацию макроэкономических, внешнеторговых и других рисков раскрыты в трудах отечественных и зарубежных ученых. (Бельский, 2017; Бельский, Карпович, 2019; Гусаков, Шпак, Киреенко, Казакевич, Байгот, 2017; Гусаков, Шпак, Киреенко, Кондратенко, 2018; Дайнеко, 2012; Догиль, 2018; Ильина, 2012; Киреенко, Кузнецова, 2019; Ушачев, Папцов,

* Киреенко Наталья Владимировна (natallia_kireenko@mail.ru), доктор экономических наук, доцент, Институт повышения квалификации и переподготовки кадров АПК Белорусского государственного аграрного технического университета (г. Минск, Беларусь);

Горбатовский Александр Викторович (gorbby@tut.by), Институт системных исследований в АПК Национальной академии наук Беларуси (г. Минск, Беларусь);

Горбатовская Оксана Николаевна (hahomova@mail.ru), кандидат экономических наук, Институт системных исследований в АПК Национальной академии наук Беларуси (г. Минск, Беларусь);

Довнар Людмила Иосифовна (dovnarludmila88@gmail.com) Институт системных исследований в АПК Национальной академии наук Беларуси (г. Минск, Беларусь). 
Долгушкин, Серков, Маслова, Чекалин, 2017; Morales, 2017; Röhrig, Hardeweg, Lentz, 2018; Haberli, Oliveira, Yanaze, 2017; Olthaar, Dolfsma, Lutz, Noseleit, 2019). Современные стратегии выхода на новый уровень результативности сельскохозяйственного производства предполагают дальнейшее внедрение инновационных технологий, мониторинг возможностей возникновения рисков на основе объективной информации и наличия имеющихся ресурсов (Haberli, Oliveira, Yanaze, 2017; Röhrig, Hardeweg, Lentz, 2018). Кроме того, особенности ведения сельского хозяйства в условиях активного влияния внешних факторов и сильной зависимости от волатильности международных цен на продукцию отрасли оказывают специфическое воздействие на уровень инвестиций, скорость внедрения технологий, уровень производства и качества продукции по всей производственной цепочке (Morales, 2017; Olthaar, Dolfsma, Lutz, Noseleit, 2019). Проводимая в Республике Беларусь аграрная политика ориентирована на стимулирование повышения эффективности агропромышленного комплекса с учетом его государственной поддержки на основе дальнейшей модернизации АПК, развития ресурсосберегающих, энергоэффективных и высокотехнологичных производств и др. (Гусаков, Шпак, Киреенко, Кондратенко, 2018).

Вместе с тем в сельском хозяйстве сохраняются низкие уровни рентабельности производства и производительности труда. Учитывая экспортную ориентацию молочно-продуктового подкомплекса необходимо принять во внимание усиление конкуренции на рынке ЕАЭС и России, а также значительное влияние конъюнктуры на деятельность отечественных товаропроизводителей. Функционирование мясопродуктового подкомплекса требует решения ряда проблем производственного и экономического характера, включая обновление материально-технической базы, повышения эффективности системы обеспечения ветеринарной безопасности и контроля в рамках Евразийского экономического союза и др. ${ }^{1}$ (Кузнецова, Киреенко, Авзалов, 2019).

${ }^{1}$ Горбатовская О.Н. 2019. Механизм совершенствования территориальной дифференциации сельскохозяйственного производства Республики Беларусь в условиях развития региональной интеграции. Минск: Институт системных исследований в АПК НАН Беларуси.
Цель статьи - проведение комплексного анализа внешней экономической среды функционирования отраслей животноводства с позиции импортоемкости продукции и уровня ее конкурентоспособности на рынке ЕАЭС. Изучение зависимости отрасли от импортных поставок ресурсов в разрезе отдельных их видов: кормов, ветеринарных препаратов и племенного скота позволит определить возможности и основные направления ее развития с учетом активного участия страны в мировых и региональных интеграционных процессах.

Корма. Интенсивное развитие животноводства в Республике Беларусь и его ориентация на наращивание объемов производства требуют обеспечения устойчивости развития кормовой базы, сбалансированности кормления сельскохозяйственных животных и рационального использования кормовых ресурсов.

Анализ стоимости кормов, израсходованных в животноводстве, и их структуры по каналам поступления в сельскохозяйственных организациях за 2014-2018 гг. показал, что удельный вес покупных кормовых ресурсов превышает $30 \%$ и характеризуется нисходящей динамикой, при этом в их структуре доля импортных составляет 13-16\%. В общей стоимости кормов импортные ресурсы занимают незначительную часть $-5-6 \%$ (рис. 1).

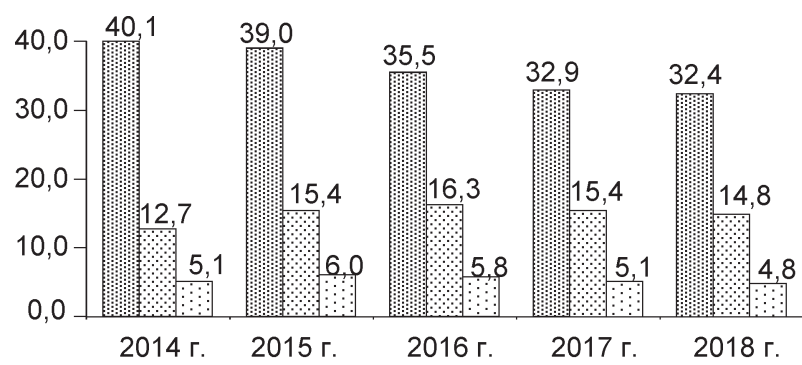

Доля покупных кормов в общей стоимости кормов, израсходованных в животноводстве, \%

- Доля импортных кормов в стоимости покупных, \% Доля имортных кормов в общей стоимости кормов, израсходованных в животноводстве, \%

Рис. 1. Расход кормов на производство животноводческой продукции в сельскохозяйственных организациях, 2014-2018 гг.

Источник. Данные сводных годовых отчетов сельскохозяйственных организаций системы Министерства сельского хозяйства и продовольствия Республики Беларусь. 
Вместе с тем, сырьевая импортная составляющая при производстве комбикормов для различных видов сельскохозяйственных животных, производимых в республике, ежегодно превышает $15 \%$, а в отдельные годы приближается к 40\% (табл. 1). В затратах на сырье доля импортных ресурсов при производстве комбикормов для КРС составляет 15$28 \%$, свиней - 14-22\%, птицы - 16-38\%. Динамика показателей неустойчива по годам.

Исследования показывают, что импортная составляющая в затратах на корма в производстве продукции животноводства составляет до 20,0\% (молока - 15-21\%, мяса КРС - $12-20 \%$, мяса свиней $-14-20 \%$, мяса птицы - 18-35\%)2. В республику ежегодно импортируется более 0,8 млн т кормов стоимостью свыше 300 млн долл. США ${ }^{3}$. Более $90 \%$ в объеме и $70 \%$ в стоимости импортируемых кормов для сельскохозяйственных животных занимают жмыхи и другие твердые отходы, полученные при извлечении растительных масел, причем их доля за период 2014-2018 гг. выросла на 2,7 п. п. и составила в 2018 г. 94,6\%, против 91,9\% - в 2014 г. В натуральном выражении объем закупаемых жмыхов находится в пределах от 817 тыс. т (2016 г.) до 1037,4 тыс. т (2017 г.).

Основной поставщик соевого жмыха Аргентина, других видов - Украина и Россия. Средняя импортная цена на соевый шрот за указанный период снизилась на $27,2 \%$, на другие виды - на 11,0\%, причем наимень-

${ }^{2}$ Гусаков В.Г., Шпак А.П., Киреенко Н.В. 2018. Продовольственная безопасность Республики Беларусь. Мониторинг2017: в контексте устойчивого функционирования АПК. Минск: Институт системных исследований в АПК НАН Беларуси.

3 URL: https://www.belstat.gov.by// ший уровень цен отмечен в 2017 г., когда они опустились до 393,4 и 187,1 долл. США/т соответственно. Доля готовых кормов в натуральном и стоимостном выражении составляет до 5 и $23 \%$ соответственно.

Сильная зависимость отраслей животноводства Беларуси от ценовой конъюнктуры на мировом рынке продуктов переработки семян масличных культур ввиду их значительных поставок в страну оказывает серьезное влияние на себестоимость животноводческой продукции и обусловливает необходимость развития в стране импортозамещающих производств, в том числе на основе переработки импортного сырья (соевых бобов).

В настоящее время в Беларуси развивается переработка сои в кормовых целях, функционирует ряд маслоэкстракционных предприятий, производящих соевый шрот, соевую муку и нерафинированное соевое масло высокого качества (ООО «Агропродукт» Брестской области ${ }^{4}$, ООО «Соя-Север» ${ }^{5}$ и ООО «Тактфест» Минской области $\left.{ }^{6}\right)$. В качестве сырья используются как импортные соевые бобы, поставки которых выросли за период 2014-2018 гг. с 4,5 до 389 тыс. т при средней цене от 380 до 650 долл. США/т (рис. 2), так и выращенные в республике. Основными потребителями данной продукции выступают крупные птицефабрики и свиноводческие комплексы.

Необходимо отметить, что себестоимость производимых в республике продуктов переработки сои (соевый шрот, соевая мука)

\footnotetext{
${ }^{4}$ URL: https://agroprodukt-oil.by/ru/главная/\#contact

${ }^{5}$ URL: https://sever.by/

${ }^{6}$ URL: http://www.taktfest.by/
}

Таблица 1

Производство комбикормов для сельскохозяйственных животных в Республике Беларусь, 2014-2018 гг.

\begin{tabular}{|l|c|c|c|c|c|c|}
\hline $\begin{array}{c}\text { Наименование } \\
\text { продукции }\end{array}$ & 2014 г. & 2015 г. & 2016 г. & 2017 г. & 2018 г. & $\begin{array}{c}2018 \text { г. } \\
\text { к уровню2014 г., \% }\end{array}$ \\
\hline \multicolumn{7}{|c|}{ Объем производства, т } \\
\hline Комбикорм для КРС & 926912 & 1149944 & 1104163 & 1114344 & 966301 & 104,2 \\
\hline для свиней & 457882 & 802710 & 813340 & 760477 & 661891 & 144,6 \\
\hline для птицы & 257174 & 513075 & 505220 & 459200 & 443553 & 172,5 \\
\hline \multicolumn{7}{|c|}{ Импортная составляющая в затратах на сырье и основные материалы, \% } \\
\hline Комбикорм для КРС & 19,3 & 28,3 & 14,6 & 16,0 & 15,1 & $-4,2$ \\
\hline для свиней & 15,7 & 22,2 & 19,6 & 21,6 & 14,4 & $-1,3$ \\
\hline для птицы & 15,6 & 27,4 & 38,4 & 31,0 & 33,1 & 17,5 \\
\hline
\end{tabular}

Источник. Рассчитано по данным Национального статистического комитета Республики Беларусь. 


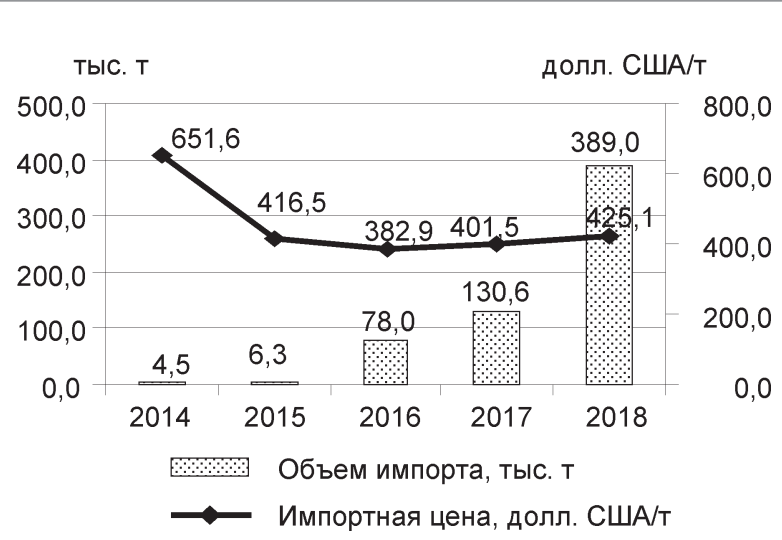

Рис. 2. Импорт соевых бобов в Республику Беларусь, 2014-2018 гг.

Источник. Авторская разработка на основе данных Национального статистического комитета Республики Беларусь.

ниже импортируемых, что делает развитие данной отрасли экономически целесообразным (Васильев, Левкина, 2017) и может быть рассмотрено в качестве перспективного направления укрепления кормовой базы животноводства и снижения импортоемкости производства мясной и молочной продукции.

Факторами, снижающими эффективность выращивания соевых бобов, выступают: низкая урожайность культуры, значительные потери при уборке, недостаточное количество пригодных для возделывания сортов и запрет на скармливание животным без предварительной термообработки.

Ветеринарные препараты. Несмотря на то, что Беларусь обладает достаточно развитой базой по производству ветеринарных препаратов (49 предприятий, 150 компаний осуществляют дистрибьюторскую деятельность в этой сфере) импортная составляющая в данной статье затрат достигает 30\%. Поставку ветеринарных вакцин на внутренний рынок осуществляют, в основном, ОАО «Белвитунифарм» и РУП «Институт экспериментальной ветеринарии им. С.Н. Вышелесского». Импорт вакцин в республику остается высоким: по итогам 2018 г. этот показатель составил 216 т стоимостью 40,6 млн долл. США, причем уровень цен ежегодно растет (темп роста за 2014-2018 гг. достиг 140,8\%) (рис. 3).

Планируется, что основным направлением решения проблемы импортозамещения средств защиты сельскохозяйственных животных является реализация совместных

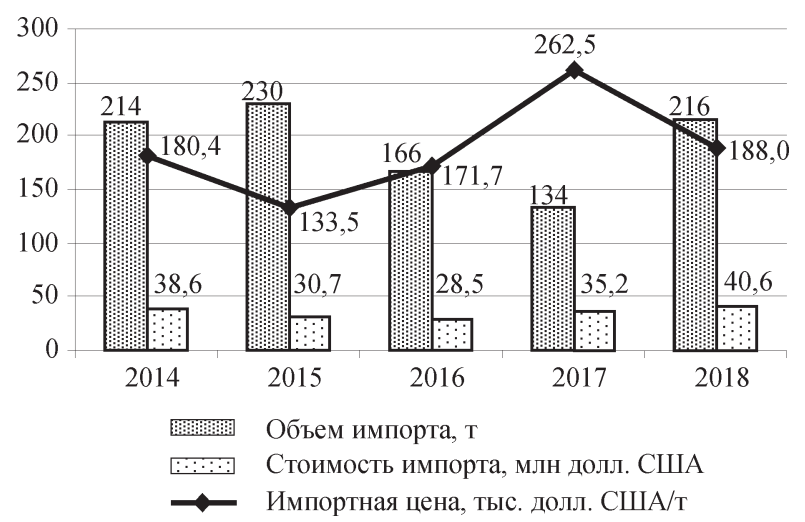

Рис. 3. Импорт ветеринарных вакцин в Республику Беларусь, 2014-2018 гг.

Источник. Авторская разработка на основе данных Национального статистического комитета Республики Беларусь.

с государствами - членами ЕАЭС межотраслевых проектов по развитию импортозамещающих производств с участием ведущих национальных научных организаций и производителей, в том числе в рамках функционирующей Евразийской сельскохозяйственной технологической платформы.

Племенной скот. Значимым фактором эффективного функционирования отраслей животноводства является высокий генетический потенциал сельскохозяйственных животных. В настоящее время существенная работа в данном направлении проводится на уровне Евразийского экономического союза. Так, Коллегией ЕЭК приняты рекомендации: «О развитии сотрудничества государств - членов ЕАЭС в сфере производства мяса крупного рогатого скота» ${ }^{7}, \ll \mathrm{O}$ развитии сотрудничества государств - членов в сфере производства свинины» ${ }^{8}, \ll \mathrm{O}$ развитии сотрудничества государств - членов Евразийского экономического союза в сфере производства молока и молочной продукции» ${ }^{9}$. Реализация указанных документов направлена на обеспечение эффективности отраслей животноводства путем снижения импортной зависимости товаропроизводителей от поставок генетического материала, сырья, средств производства, развития исследовательской деятельности, привлечения дополнительных ин-

7 URL: http://www.pravo.by/document/?guid= $3871 \& \mathrm{p} 0=\mathrm{F} 01900075$

8 URL: https://www.etalonline.by/document/ ?regnum $=\mathrm{f} 01900245 \& \mathrm{q}$ id $=$

9 URL: https://www.etalonline.by/document/ ?regnum=f01900246\&q_id $=$ 
вестиций за счет реализации кооперационных проектов, повышения производственного и экспортного потенциала мясного и молочного подкомплексов.

Перечисленные направления особенно актуальны для Беларуси, обладающей значительным научным и практическим потенциалом в данной сфере. В настоящее время в специализированных хозяйствах республики содержатся 13355 гол. высокопродуктивных коров селекционного стада молочного направления, среднегодовая продуктивность которых достигает 9815 кг молока (содержание жира $-3,93 \%$, белка - 3,32\%), в племенных хозяйствах - 4749 гол. коров с продуктивностью свыше 10000 кг (содержание жира - свыше 3,6\%, белка - свыше 3,1\%).

Разведением мясного скота сегодня занимаются 202 предприятия (в 2014 г. - 297), основное количество которых (50\% от числа по республике) сосредоточено в Брестской и Витебской областях. Также сокращается и поголовье скота в мясном скотоводстве (за 2014-2017 гг. на 31,1\%), численность которого по итогам 2017 г. составила 64,3 тыс. гол.

Исследования показали, что наибольшие объемы импорта в страну чистопородных племенных животных наблюдались в 2015-2017 гг. (табл. 2). Этому способствовали проведение селекционно-племенной работы, выделение средств на удешевление стоимости и объема племенной продукции и другие мероприятия, предусмотренные в подпрограмме «Развитие племенного дела в животноводстве» Государственной программы развития аграрного бизнеса в Республике Беларусь на 2016-2020 годы ${ }^{10}$.

10 URL: http://www.pravo.by/upload/docs/op/ C21900278_1558126800.pdf
Дальнейшее развитие племенного скотоводства в Беларуси должно включать комплекс экономических, технологических, организационных и инновационно-биологических мер, среди которых нами выделены: создание информационных баз данных о геномах, внедрение генетической паспортизации сельскохозяйственных животных с высокой продуктивностью, использование инновационных технологий проведения геномной селекции, государственная поддержка производителей племенной продукции, страхование и развитие инфраструктуры и др.

Система производства и сбыта животноводческой продукции Республики Беларусь зависит от проводимой агропромышленной политики государств - членов ЕАЭС, которая определяет основные приоритеты развития отрасли, а также направления повышения уровня производства и конкурентоспособности продукции.

\section{Уровень производства продукции животноводства в государствах - членах ЕАЭС}

Исследования показывают, что экспортная ориентация мясного и молочного подкомплексов Республики Беларусь, главным образом, на рынок государств - членов ЕАЭС обусловливает зависимость динамики развития национальных сегментов от реализуемых стратегических направлений и сложившихся тенденций развития отраслей животноводства Союза. За период 2014-2018 гг. производство молока в целом по ЕАЭС увеличилось на 3,7\%, мяса скота и птицы - на 17,3\%. Выявлено, что наиболее динамично отрасль молочного скотоводства развивается в Бела-

Таблица 2

Импорт чистопородных племенных животных крупного рогатого скота и свиней в Республику Беларусь, 2014-2018 гг.

\begin{tabular}{|c|c|c|c|c|c|c|}
\hline \multirow{2}{*}{ Год } & \multicolumn{5}{|c|}{ Импорт чистопородных племенных животных } \\
\cline { 2 - 7 } & \multicolumn{3}{|c|}{ крупный рогатый скот } & \multicolumn{3}{c|}{ свиньи } \\
\cline { 2 - 7 } & гол. & $\begin{array}{c}\text { тыс. долл. } \\
\text { США }\end{array}$ & $\begin{array}{c}\text { средняя цена, } \\
\text { долл. США/гол. }\end{array}$ & гол. & $\begin{array}{c}\text { тыс. долл. } \\
\text { США }\end{array}$ & $\begin{array}{c}\text { средняя цена, } \\
\text { долл. США/гол. }\end{array}$ \\
\hline 2014 & 762 & 2078,7 & 2728,0 & 1322 & 2685,4 & 2031,3 \\
\hline 2015 & 1752 & 4775,2 & 2725,6 & 3268 & 3740,7 & 1144,6 \\
\hline 2016 & 1152 & 3285,1 & 2851,6 & 6693 & 6553,7 & 979,2 \\
\hline 2017 & 678 & 2006,2 & 2959,0 & 3026 & 4210,6 & 1391,5 \\
\hline 2018 & 948 & 2804,9 & 2958,8 & 979 & 1522,2 & 1554,9 \\
\hline
\end{tabular}

Источник. Авторская разработка по данным Национального статистического комитета Республики Беларусь. 
руси и Казахстане, где темпы роста производства молока за указанный период составили 109,6 и 112,2\%, продуктивности коров - 110,1 и 102,9\% соответственно. В России валовой надой молока увеличился на 2,1\% при росте среднегодовой продуктивности коров на 11,7\%, Кыргызстане - на 10,0\% при снижении удоя молока на одну корову на 1,4\%. В Армении после сложившейся тенденции роста в 2018 г. производство молока снизилось до 697,7 тыс. т.

Рост производства мяса скота и птицы отмечается во всех государствах - членах: по итогам 2014-2018 гг. темп прироста составил в Армении 16,2\%, Беларуси 14,3, Казахстане - 17,7, Кыргызстане - 9,0 и России - 17,8\% (табл. 3).

Вместе с тем, уровень производства продукции животноводства характеризуется сильной дифференциацией в разрезе государств-членов. Так, если в Беларуси на 100 га сельскохозяйственных угодий производится 864 ц молока и 203 ц мяса (в оценке по живому весу), то в Казахстане 56 и 18 ц соответственно, что является самым низким показателем среди других стран ЕАЭС и свидетельствует о недостаточной развитости отраслей (табл. 4).
Обеспеченность населения продукцией собственного производства также различна. Выявлено, что в Беларуси сложившиеся объемы производства позволяют удовлетворить внутренние потребности в молоке и мясе на 235,1 и 135,2\% соответственно, и в расчете на душу населения превышают рациональные нормы потребления. В остальных странах (за исключением Кыргызстана) уровень развития национального сегмента не способен полностью обеспечить внутренние потребности, что обусловливает необходимость поставок импортной продукции (табл. 5).

Конкурентоспособность продукции животноводства. Исследования показывают, что в условиях наличия барьеров, изъятий и ограничений во взаимной торговле между государствами - членами ЕАЭС для Беларуси особенно актуальным является вопрос повышения конкурентоспособности собственной продукции на внешнем рынке. В связи с этим нами проведена оценка конкурентных преимуществ отраслей животноводства Беларуси в условиях функционирования ЕАЭС по следующим показателям: цена производителей продукции животноводства, уровень продуктивности

Таблица 3

Производство отдельных видов продукции животноводства в государствах - членах ЕАЭС, 2014-2018 гг.

\begin{tabular}{|l|c|c|c|c|c|c|}
\hline \multicolumn{1}{|c|}{ Государство } & 2014 г. & 2015 г. & 2016 г. & 2017 г. & 2018 г. & $\begin{array}{c}2018 \text { г. } \\
\text { к уровню 2014 г., \% }\end{array}$ \\
\hline Армения & 700,4 & 728,6 & 754,2 & 758,2 & 697,7 & 99,6 \\
\hline Беларусь & 6703,0 & 7047,0 & 7140,0 & 7321,0 & 7345,0 & 109,6 \\
\hline Казахстан & 5067,9 & 5182,4 & 5341,6 & 5503,4 & 5686,2 & 112,2 \\
\hline Кыргызстан & 1445,5 & 1481,0 & 1524,6 & 1556,2 & 1589,7 & 110,0 \\
\hline Россия & 29995,2 & 29887,5 & 29787,2 & 30184,5 & 30611,2 & 102,1 \\
\hline \multicolumn{7}{|c|}{ Среднегодовой удой молока, кг } \\
\hline Армения & 2102 & 2144 & 2192 & 2260 & 2300 & 109,4 \\
\hline Беларусь & 4508 & 4722 & 4813 & 4942 & 4962 & 110,1 \\
\hline Казахстан & 2275 & 2321 & 2324 & 2337 & 2340 & 102,9 \\
\hline Кыргызстан & 2009 & 1998 & 1978 & 1984 & 1981,8 & 98,6 \\
\hline Россия & 4021 & 4134 & 4218 & 4368 & 4492 & 111,7 \\
\hline \multicolumn{7}{|c|}{ Производство скота и птицы (в убойном весе), тыс. т } \\
\hline Армения & 93,1 & 100,4 & 106,1 & 109,0 & 108,2 & 116,2 \\
\hline Беларусь & 1073,0 & 1149,3 & 1172,4 & 1208,3 & 1226,4 & 114,3 \\
\hline Казахстан & 900,2 & 931,0 & 960,7 & 1017,6 & 1059,6 & 117,7 \\
\hline Кыргызстан & 202,8 & 208,3 & 212,4 & 216,6 & 221,1 & 109,0 \\
\hline Россия & 9026,0 & 9518,5 & 9853,3 & 10319,0 & 10629,4 & 117,8 \\
\hline
\end{tabular}

Источник. Авторская разработка по данным: URL:https://www.belstat.gov.by; URL: https://www.gks.ru/; URL: https://stat.gov.kz/; URL:http://www.stat.kg/; URL: https://www.armstat.am/en/ 
Производство отдельных видов продукции животноводства в расчете на 100 га сельскохозяйственных угодий в государствах - членах ЕАЭС, ц

\begin{tabular}{|c|c|c|c|c|c|c|}
\hline Государство & 2014 г. & 2015 г. & 2016 г. & 2017 г. & 2018 г. & $\begin{array}{c}2018 \text { г. к уровню } \\
2014 \text { г., \% }\end{array}$ \\
\hline \multicolumn{7}{|c|}{ Молоко } \\
\hline Армения & 342 & 356 & 369 & 371 & 342 & 100,0 \\
\hline Беларусь & 781 & 829 & 844 & 857 & 864 & 110,6 \\
\hline Казахстан & 53 & 53 & 54 & 55 & 56 & 104,9 \\
\hline Кыргызстан & 189 & 188 & 186 & 187 & 187 & 98,8 \\
\hline Россия & 158 & 156 & 155 & 156 & 158 & 100,3 \\
\hline \multicolumn{7}{|c|}{ Произведено скота и птицы на убой (в живом весе) } \\
\hline Армения & 80 & 86 & 92 & 94 & 93 & 116,9 \\
\hline Беларусь & 180 & 195 & 198 & 196 & 203 & 112,8 \\
\hline Казахстан & 17 & 17 & 17 & 18 & 18 & 109,5 \\
\hline Кыргызстан & 35 & 36 & 37 & 37 & 38 & 109,5 \\
\hline Россия & 67 & 70 & 72 & 75 & 77 & 114,6 \\
\hline
\end{tabular}

Источник. Авторская разработка по данным: URL:https://www.belstat.gov.by; URL: https://www.gks.ru/; URL: https://stat.gov.kz/; URL:http://www.stat.kg/; URL: https://www.armstat.am/en/

сельскохозяйственных животных, рентабельность производства.

Анализ цен производителей молока сырого в долларовом эквиваленте показал, что в Беларуси отмечается наименьший их уровень (до 300 долл. США/т), обеспечивающий преимущества для обрабатывающих предприятий в части стоимости сырья. В Армении в течение 2016-2018 гг. уровень цены варьировал в пределах 285315 долл. США/т, Казахстане - 247-323, Кыргызстане - 279-306, России - 326-420 долл. США/т (рис. 4).

Однако более детальная оценка затрат и эффективности производства молока коровьего в сравнении с другими государства- ми ЕАЭС (Казахстаном) показала, что для Беларуси характерна относительно высокая себестоимость молока. Значительные затраты на производство молока при невысоких ценах их реализации являются причиной более низкой рентабельности отрасли по сравнению со странами ЕАЭС. Так, по итогам 2018 г. производственные затраты на 1 т молока в Беларуси составили 219,1 долл. США, в Казахстане - 195,1 долл. США, уровень рентабельности - 26,2 и 35,6\% соответственно (табл. 6-7).

Аналогичная ситуация характерна и для мясной отрасли. В течение 20162018 гг. цена производителей мяса КРС в Беларуси находилась на уровне 1100-

Производство отдельных видов продукции животноводства в расчете на душу населения, кг

\begin{tabular}{|l|c|c|c|c|c|c|}
\hline \multicolumn{1}{|c|}{ Государство } & 2014 г. & 2015 г. & 2016 г. & 2017 г. & 2018 г. & $\begin{array}{c}2018 \text { г. к уровню } \\
2014 \text { г., \% }\end{array}$ \\
\hline \multicolumn{7}{|c|}{ Молоко } \\
\hline Армения & 232 & 242 & 252 & 254 & 235 & 101,3 \\
\hline Беларусь & 707 & 743 & 751 & 771 & 775 & 109,6 \\
\hline Казахстан & 293 & 295 & 300 & 380 & 311 & 106,1 \\
\hline Кыргызстан & 248 & 249 & 251 & 251 & 251 & 101,2 \\
\hline Россия & 205 & 204 & 203 & 206 & 208 & 101,5 \\
\hline \multicolumn{7}{|c|}{ Произведено скота и птицы на убой (в убойном весе) } \\
\hline Армения & 31 & 33 & 35 & 37 & 36 & 116,1 \\
\hline Беларусь & 113 & 121 & 123 & 127 & 129 & 114,2 \\
\hline Казахстан & 52 & 53 & 54 & 55 & 58 & 111,5 \\
\hline Кыргызстан & 34 & 35 & 36 & 35 & 35 & 102,9 \\
\hline Россия & 62 & 65 & 67 & 70 & 72 & 116,1 \\
\hline
\end{tabular}

Источник. Авторская разработка по данным: URL:https://www.belstat.gov.by; URL: https://www.gks.ru/; URL: https://stat.gov.kz/; URL:http://www.stat.kg/; URL: https://www.armstat.am/en/ 
Внешние условия и факторы функционирования отраслей животноводства Республики Беларусь

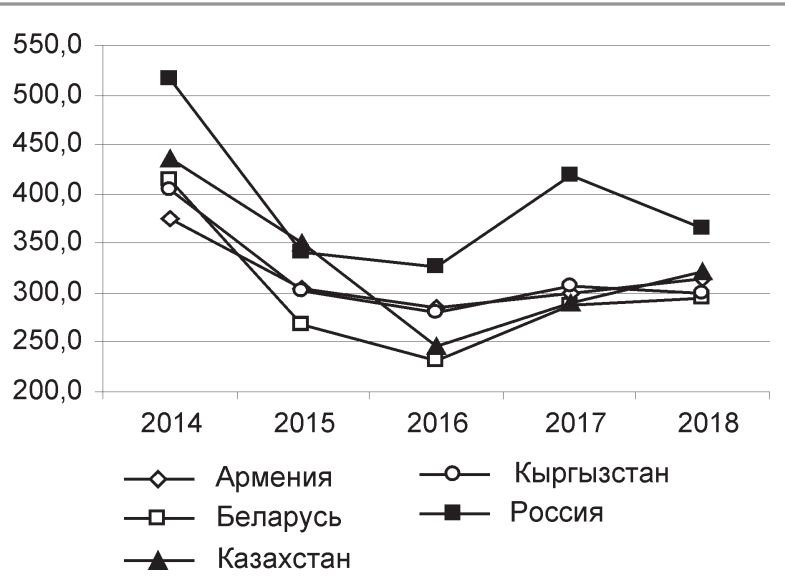

Рис. 4. Цены производителей молока сырого коровьего в государствах - членах ЕАЭС, 2014-2018 гг., долл. США/т

Источник. Авторская разработка по данным: URL: https://www.belstat.gov.by; URL: https://www.gks.ru/; URL: https://stat.gov.kz/; URL: http://www.stat.kg/; URL: https://www.armstat.am/en/

1212 долл. США/т, в Казахстане - 13691668, Кыргызстане - 2159-2449, России 1443-1673, Армении - 2258-3085 долл. США/т (рис. 5). В Беларуси отрасль мясного скотоводства убыточна, что кроме низких закупочных цен связано с высокими затратами на выращивание. В данных условиях важнейшими направлениями ее раз-

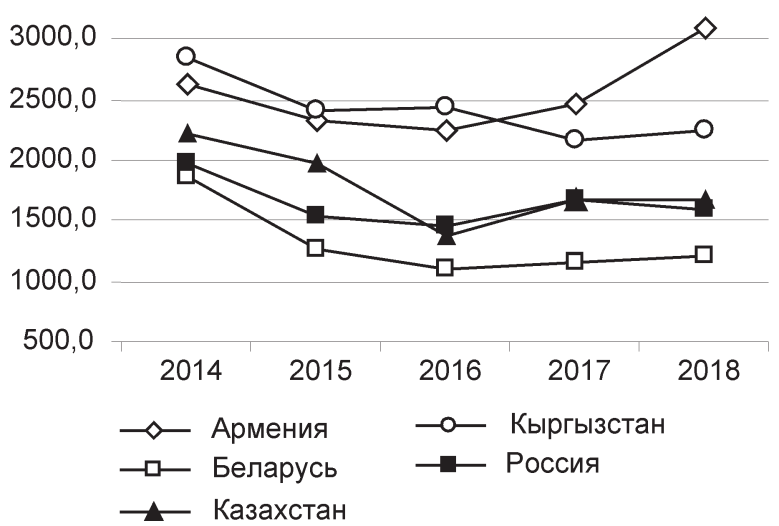

Рис. 5. Цены производителей мяса крупного рогатого скота в государствах - членах ЕАЭС, 2014-2018 гг., долл. США/т

Источник. Авторская разработка по данным: URL: https://www.belstat.gov.by; URL: https://www.gks.ru/; URL: https://stat.gov.kz/; URL: http://www.stat.kg/; URL: https://www.armstat.am/en/

вития должны стать совершенствование ценообразования на продукцию мясного скотоводства и бухгалтерского учета затрат.

Указанная дифференциация государств - членов ЕАЭС по показателям цены сохраняется и в других отраслях животноводства, в частности, в свиноводстве и птицеводстве (рис. 6-7).

Таблица 6

Затраты на производство молока коровьего и продукции выращивания КРС в сельскохозяйственных организациях Беларуси и Казахстана, 2014-2018 гг., долл. США/т

\begin{tabular}{|l|c|c|c|c|c|c|}
\hline \multicolumn{1}{|c|}{ Страна } & 2014 г. & 2015 г. & 2016 г. & 2017 г. & 2018 г. & $\begin{array}{c}2018 \text { г. к уровню 2014 } \\
\text { Г., \% }\end{array}$ \\
\hline \multicolumn{7}{|c|}{ Молоко коровье } \\
\hline Беларусь & 324,9 & 222,8 & 184,5 & 211,4 & 219,1 & 67,4 \\
\hline Казахстан & 335,3 & 272,5 & 169,5 & 211,1 & 199,5 & 59,5 \\
\hline \multicolumn{7}{|c|}{ Продукция выращивания крупного рогатого скота } \\
\hline Беларусь & 2697,9 & 1889,7 & 1551,9 & 1575,7 & 1866,3 & 69,2 \\
\hline Казахстан & 2515,4 & 2055,8 & 1373,0 & 1480,1 & 1265,9 & 50,3 \\
\hline
\end{tabular}

Источник. Авторская разработка по данным: URL: https://www.belstat.gov.by; URL: https://stat.gov.kz

Таблица 7

Уровень рентабельности реализации молока коровьего и продукции выращивания КРС в сельскохозяйственных организациях Беларуси и Казахстана, 2014-2018 гг., \%

\begin{tabular}{|l|c|c|c|c|c|c|}
\hline \multicolumn{1}{|c|}{ Государство } & 2014 г. & 2015 г. & 2016 г. & 2017 г. & 2018 г. & $\begin{array}{c}2018 \text { г. к уровню } \\
2014 \text { г., П. П. }\end{array}$ \\
\hline \multicolumn{7}{|c|}{ Молоко коровье } \\
\hline Беларусь & 19,2 & 15 & 18,7 & 28,4 & 26,2 & 7,0 \\
\hline Казахсан & 31,4 & 23,7 & 30,1 & 29,5 & 35,6 & 4,2 \\
\hline \multicolumn{7}{|c|}{ Продукция выращивания крупного рогатого скота } \\
\hline Беларусь & $-25,3$ & $-31,8$ & $-34,8$ & $-33,6$ & $-35,6$ & $-10,3$ \\
\hline Казахстан & 11 & 8,8 & 9,8 & 14,9 & 16,2 & 5,2 \\
\hline
\end{tabular}

Источник. Авторская разработка по данным: URL: https://www.belstat.gov.by; URL: https://stat.gov.kz 


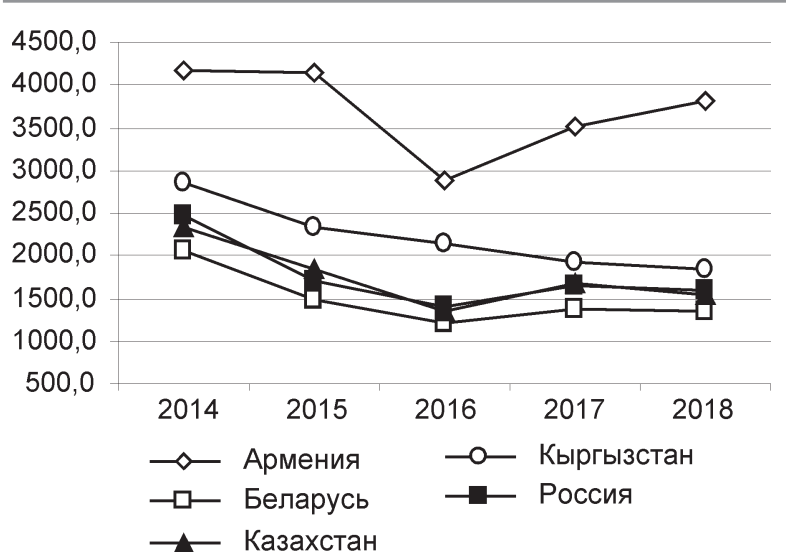

Рис. 6. Цены производителей мяса свиней в государствах - членах ЕАЭС, 2014-2018 гг., долл. США/т

Источник. Авторская разработка по данным: URL: https://www.belstat.gov.by; URL: https:// www.gks.ru/; URL: https://stat.gov.kz/; URL: http:// www.stat.kg/; URL: https://www.armstat.am/en/

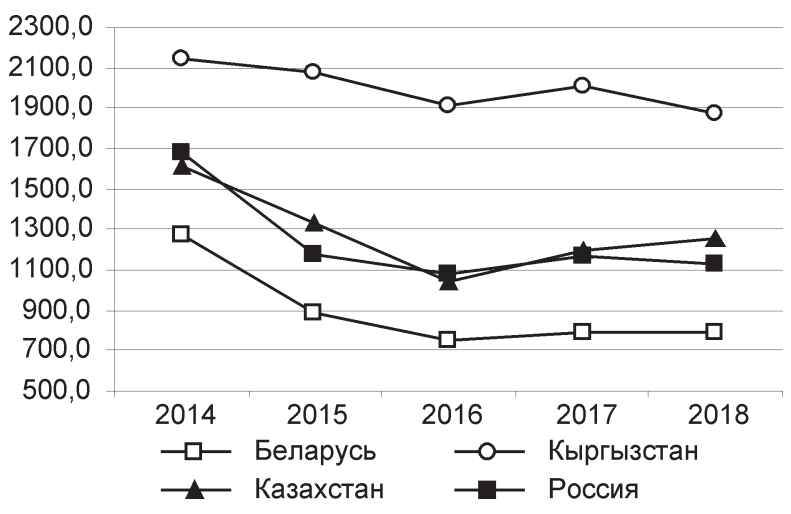

Рис. 7. Цены производителей мяса птицы в государствах - членах ЕАЭС, 2014-2018 гг., долл. США/т

Источник. Авторская разработка по данным: URL: https://www.belstat.gov.by; URL: https://www.gks.ru/; URL: https://stat.gov.kz/; URL: http://www.stat.kg/; URL: https:/ /www.armstat.am/en/

\section{Приоритеты и направления развития отраслей животноводства в государствах - иленах ЕАЭС}

Исследование программных документов в области развития национальных АПК государств - членов ЕАЭС показало, что в Армении, согласно Стратегии устойчивого развития села и сельского хозяйства Республики Армения на 2010-2020 годы ${ }^{11}$, основным направлением развития отраслей

11 URL: http://www.eurasiancommission.org/ru/act/ prom_i_agroprom/dep_agroprom/sensitive_productsDocuments/ Стратегия\% 20 устойчивого\% 20 развития $\% 20$ сельского\% 20 хозяйства $\% 20$ Республики $\% 20$ Армения $\% 20$ на $\% 202010 \%$ $202020 \% 20$ г.pdf животноводства определено достижение полного самообеспечения продукцией собственного производства. В связи с этим к 2020 г. планируется увеличение поголовья сельскохозяйственных животных (КРС до 667 тыс. гол., коров - 328,5, овец и коз 1550 тыс. гол.) и их продуктивности (удоя молока - до 2480 кг, среднесуточного привеса КРС - 550 г, овец и коз - 155 г) за счет развития кормовой базы и племенного животноводства, эффективного размещения отраслей и др. (табл. 8).

В Республике Беларусь в условиях насыщения внутреннего рынка продукцией животноводства актуальными задачами являются снижение импортоемкости ее производства, повышение конкурентоспособности продукции на рынке государств - членов ЕАЭС и эффективности функционирования отраслей. Основными целевыми индикаторами развития животноводства согласно действующей Государственной программе развития аграрного бизнеса в Республике Беларусь на 2016-2020 гг. определены: увеличение объемов производства продукции животноводства в хозяйствах всех категорий на 18,3\% (к уровню 2015 г.), рост объемов производства молока до 9,2 млн т, яиц - до 3914 млн шт., реализации скота и птицы в живом весе - до 1875 тыс. т. Достижение указанных показателей предусмотрено за счет укрепления кормовой базы в части обеспечения необходимого числа и объема хранилищ, запасов травяных кормов, проведения селекционно-племенной работы и др. ${ }^{12}$

В Казахстане, в условиях низкого уровня производства продукции животноводства и зависимости от импорта, перспективное развитие отраслей предполагает создание прочной кормовой базы, стимулирование приобретения племенных животных, модернизацию существующих свиноводческих комплексов и ферм, создание семейных и промышленных молочно-товарных ферм и птицефабрик. Реализация указанных направлений согласно Государственной программе развития агропромышленного комплекса Республики Казахстан на 2017-2021 годы позволит повысить уровень обеспеченности грубыми кормами до 112\%,

12 URL: http://www.pravo.by/upload/docs/op/ C21900278_1558126800.pdf 
Стратегические программы развития агропромышленного комплекса государств - членов ЕАЭС в части производства продукции животноводства (сырья)

\begin{tabular}{|c|c|c|c|}
\hline Государство & $\begin{array}{c}\text { Наименование } \\
\text { программного } \\
\text { документа }\end{array}$ & Целевые индикаторы развития & Приоритетные направления развития \\
\hline $\begin{array}{l}\text { Республика } \\
\text { Армения }\end{array}$ & $\begin{array}{l}\text { Стратегия } \\
\text { устойчивого } \\
\text { развития села и } \\
\text { сельского хозяйства } \\
\text { Республики } \\
\text { Армения } \\
\text { на 2010-2020 годы }\end{array}$ & $\begin{array}{l}2020 \text { год: Молоко: } \\
\text { увеличение молочной продуктивности коров до } \\
2480 \text { кг, овец и коз - до 106,4 кг; поголовья коров - } \\
\text { до } 328,5 \text { тыс. гол.; объемов производства молока до } \\
974,2 \text { тыс. т, в том числе коровьего - } 850,5 \text { тыс. т, } \\
\text { овечьего и козьего - } 123,7 \text { тыс. т. } \\
\text { Мясо: } \\
\text { увеличение среднесуточного прироста КРС до } 550 \text { г, } \\
\text { овец и коз - } 155 \text { г, свиней - } 330 \text { г, птицы - } 1,4 \text { г; } \\
\text { поголовья КРС на конец года - до } 667 \text { тыс. гол., } \\
\text { свиней - } 210, \text { овец и ко3 - } 1550, \text { птицы - } 8000, \\
\text { лошадей - 13,0 тыс. т; объема реализации скота и } \\
\text { птицы на убой в живом весе - до } 183,5 \text { тыс. т, в том } \\
\text { числе мяса КРС - 97,0 тыс. т, овец и коз - 46,5, } \\
\text { свиней - 24,0, птицы - 16,0 тыс. т. } \\
\text { Яйца: } \\
\text { увеличение средней яйценоскости до } 225 \text { шт., } \\
\text { объема производства яиц - до 750 млн шт. } \\
\text { ІІерсть: } \\
\text { рост валового объема производства шерсти } \\
\text { до } 3,56 \text { тыс. т }\end{array}$ & $\begin{array}{l}\text { Эффективное сочетание и рациональное } \\
\text { распределение отраслей животноводства. } \\
\text { Совершенствование племеннбо } \\
\text { животноводства. } \\
\text { Усовершенствование ветеринарной системы и } \\
\text { повышение эффективности ветеринарных } \\
\text { мер. } \\
\text { Развитие кормовой базы для животноводства. } \\
\text { Укрупнение хозяйств и подлержка развития } \\
\text { коммерческих животноводческих } \\
\text { организаций. } \\
\text { Обеспечение сохранениягенетического } \\
\text { разнообразия пород сельскохозяйственных } \\
\text { животных }\end{array}$ \\
\hline $\begin{array}{l}\text { Республика } \\
\text { Беларусь }\end{array}$ & \begin{tabular}{|l|} 
Государственная \\
программа развития \\
аграрного бизнеса в \\
Республике \\
Беларусь \\
на 2016-2020 годы
\end{tabular} & $\begin{array}{l}2020 \text { год: } \\
\text { увеличение объемов производства продукции } \\
\text { животноводства в хозяйствах всех категорий на } \\
\text { 18,3\% (к уровню } 2015 \text { г.); } \\
\text { Молоко: } \\
\text { рост объема производства молока до 9,2 млн т; } \\
\text { Мясо: } \\
\text { увеличение объема реализации скота и птицы в } \\
\text { живом весе - до } 1875 \text { тыс. т, в том числе КРС - до } \\
720 \text { тыс. т (из них специализированных мясных } \\
\text { пород - } 35 \text { тыс. т), свиней - 540, птицы - } 615 \text { тыс. т; } \\
\text { Яйца: } \\
\text { увеличение объема производства яиц - } \\
\text { до } 3914 \text { млн шт. }\end{array}$ & $\begin{array}{l}\text { Освоение и техническое переоснащение } \\
\text { производственных мощностей } \\
\text { животноводческих, птицеводческих, } \\
\text { звероводческих и кролиководческих } \\
\text { объектов. } \\
\text { Укомплетование введенных в эксплуатацию } \\
\text { объектов поголовьем скота, птицы и зверей; } \\
\text { внедрение государственной информационной } \\
\text { системы в области идентификации, } \\
\text { регистрации, прослеживаемости } \\
\text { сельскохозяйственных животных. } \\
\text { Профилактика особо опасных болезней } \\
\text { животных, оснащение лабораторий и станций } \\
\text { оборудованием для диагностики болезней } \\
\text { животных. } \\
\text { Обеспечение контроля безопасности в } \\
\text { ветеринарно-санитарном отношении кормов } \\
\text { и кормовых добавок, ветеринарных } \\
\text { препаратов, сырья и пищевых продуктов }\end{array}$ \\
\hline $\begin{array}{l}\text { Республика } \\
\text { Казахстан }\end{array}$ & \begin{tabular}{|l|} 
Государственная \\
программа развития \\
агропромышленного \\
комплекса \\
Республики \\
Казахстан \\
на 2017-2021 годы
\end{tabular} & $\begin{array}{l}2021 \text { год: Молоко: } \\
\text { достижение продуктивности коров на уровне } 2406 \\
\text { кг; объема производства молока - 5665 тыс. т; } \\
\text { Мясо: } \\
\text { увеличение поголовья КРС до } 6951 \text { тыс. гол., } \\
\text { свиней - } 825, \text { овец и коз - } 21100, \text { птицы - } 48516, \\
\text { лошадей - 2957, верблюдов - } 202 \text { тыс. гол.; } \\
\text { объема реализации скота и птицы в убойном весе- } \\
\text { до } 1083 \text { тыс. т, в том числе КРС - } 491 \text { тыс. т, овец и } \\
\text { коз - 161, свиней - 133, птицы - 298 тыс. т; } \\
\text { уровень обеспеченности кормами составит: грубыми - } \\
112 \%, \text { сочными - 168, концентрированными - 42\%; } \\
\text { доля племенного скота увеличится: КРС - до } 16,9 \%, \\
\text { МРС - 17,7, свиней - 17,9, лошадей - } 8, \text { птицы - } 31,2 \% ; \\
\text { средний живой вес одной забитой головы КРС } \\
\text { составит } 377,9 \text { кг, МРС - 42, свиней - } 109, \\
\text { птицы - 2,4 кг } \\
\end{array}$ & $\begin{array}{l}\text { Создание прочной кормовой базы путем } \\
\text { разработки кормового баланса, } \\
\text { совершенствования базовых рационов } \\
\text { кормления, структуры посевов кормовых } \\
\text { культур. } \\
\text { Стимулирование приобретения племенных } \\
\text { животных за счет повышения качества } \\
\text { продукции племенных репродукторов. } \\
\text { Совершенствование инфраструктуры } \\
\text { торговли скотом за счет частных инвестиций } \\
\text { в целях снижения издержек при } \\
\text { приобретении скота. } \\
\text { Создание семейных и промышленных } \\
\text { молочно-товарных ферм, птицефабрик } \\
\text { мясного направления, повышение уровня } \\
\text { механизации производства, создание } \\
\text { племенных репродукторов. } \\
\text { Развитие нетрадиционных направлений } \\
\text { птицеводства (водоплавающая птица и } \\
\text { перепела). } \\
\text { Модернизация существующих } \\
\text { свиноводческих комплексов и ферм }\end{array}$ \\
\hline $\begin{array}{l}\text { Кыргызская } \\
\text { Республика }\end{array}$ & $\begin{array}{l}\text { Среднесрочный } \\
\text { прогноз социально- } \\
\text { экономического } \\
\text { развития } \\
\text { Кыргызской } \\
\text { Республики } \\
\text { на 2019-2021 годы }\end{array}$ & $\begin{array}{l}2021 \text { год: Молоко: } \\
\text { достижение производства молока на уровне } \\
1707 \text { тыс. т (+15,3\% к уровню } 2015 \text { г.) } \\
\text { Мясо: } \\
\text { увеличение объема реализации скота и птицы на } \\
\text { убой до 432,5 тыс. т }\end{array}$ & $\begin{array}{l}\text { Рациональное использование генофонда } \\
\text { сельскохозяйственных животных и домашней } \\
\text { птицы. } \\
\text { Повышение эффективности селекционнө } \\
\text { племенной работы и пунктов искусственного } \\
\text { осеменения животных с использованием } \\
\text { ценного генетического материала. } \\
\text { Увеличение объемов заготовки всех видов } \\
\text { кормов. } \\
\text { Оптимизация производственных процессов и } \\
\text { управления, сокращение энергетических и } \\
\text { ресурсных затрат }\end{array}$ \\
\hline
\end{tabular}


Окончание табл. 8

\begin{tabular}{|c|c|c|c|}
\hline Государство & $\begin{array}{c}\text { Наименование } \\
\text { программного } \\
\text { документа }\end{array}$ & Целевые индикаторы развития & Приоритетные направления развития \\
\hline $\begin{array}{l}\text { Российская } \\
\text { Федерация }\end{array}$ & \begin{tabular}{|l} 
Государственная \\
программа развития \\
сельского хозяйства \\
и регулирования \\
рынков \\
сельскохозяйственн \\
ой продукции, \\
сырья и \\
продовольствия на \\
$2013-2020$ \\
годы
\end{tabular} & $\begin{array}{l}\text { 2020 год: Молоко: } \\
\text { индекс производства продукции животноводства к } \\
\text { уровню 2015 г. - 110,2\%; } \\
\text { рост объемов производства молока в хозяйствах } \\
\text { всех категорий - 31,9 млн т } \\
\text { Мясо: } \\
\text { увеличение объемов производства скота и птицы на } \\
\text { убой в хозяйствах всех категорий (в живом весе) - } \\
14448,4 \text { тыс. т, в том числе КРС - до } 3,15 \text { млн т, } \\
\text { свиней - до 4,53 млн т, птицы - до 5,8 млн т, } \\
\text { прочих - до } 127,5 \text { тыс. т; } \\
\text { рост поголовья КРС специализированных мясных } \\
\text { пород и помесного скота (в сельскохозяйственных } \\
\text { организациях, КФХ, включая индивидуальных } \\
\text { предпринимателей) до 2950 тыс. гол., товарного } \\
\text { поголовья коров специализированных мясных } \\
\text { пород - 900; маточного поголовья овец и коз - 9715, } \\
\text { поголовья северных оленей и маралов - 1193, пого- } \\
\text { ловья мясных табунных лошадей до } 430 \text { тыс. гол. }\end{array}$ & $\begin{array}{l}\text { укрепление кормовой базы для } \\
\text { животноводства за счет отходов крупяной } \\
\text { промышленности в объеме } 705 \text { тыс. т, } \\
\text { сушеного жома - 500 тыс. т, шротов } \\
\text { маслосемян всех видов - } 7870 \text { тыс. т; } \\
\text { строительство, реконструкция } \\
\text { (модернизация) производственных объектов } \\
\text { по убою и первичной переработке скота в } \\
\text { рамках единого производственного цикла, } \\
\text { включающего основные этапы } \\
\text { производственной цепочки; } \\
\text { повышение качественных характеристик } \\
\text { молочного сырья; } \\
\text { техническое переоснащение } \\
\text { молочнотоварных ферм; } \\
\text { развитие инфраструктуры и логистического } \\
\text { обеспечения }\end{array}$ \\
\hline
\end{tabular}

Источник. Авторская разработка по данным: URL: https://www.belstat.gov.by; URL: https://www.gks.ru/; URL: https://stat.gov.kz/; URL:http://www.stat.kg/; URL: https://www.armstat.am/en/

сочными - 168, концентрированными $42 \%$; долю племенного КРС - до 16,9\%, МРC - 17,7, свиней - 17,9, лошадей - 8, птицы - 31,2\%, что обусловит рост объемов производства молока до 5665 тыс. т, реализации мяса - до 1083 тыс. т¹3.

В Кыргызстане по молоку достигнуто полное самообеспечение внутренних потребностей, мясу - превышает 90\%. Исходя из этого, в рамках реализации Среднесрочного прогноза социально-экономического развития Кыргызской Республики на 2019-2021 годы предусмотрено достижение производства молока на уровне 1707 тыс. т (+15,3\% к уровню 2015 г.), реализации скота и птицы на убой до 432,5 тыс. т на основе рационального использования генофонда сельскохозяйственных животных, развития селекционно-племенной работы, укрепления сырьевой базы, оптимизации производственных процессов и управления ${ }^{14}$.

Российская Федерация в настоящее время реализует комплекс мер для достижения продовольственной безопасности в отношении продукции животноводства. Согласно Государственной программе развития сельского хозяйства и регулирования рынков сельскохозяйственной продукции, сырья и продовольствия на 20132020 годы $^{15}$ предусматривается укрепление

${ }^{13}$ URL: https://online.zakon.kz/m/Document/?doc_ id $=32033682$

${ }^{14}$ URL: http://cbd.minjust.gov.kg/act/properties/ru-ru/ $12307 / 10$

${ }_{15}$ URL: https://www.garant.ru/products/ipo/prime/doc/ 70110644/ кормовой базы, строительство, реконструкция (модернизация) производственных объектов, повышение качественных характеристик молочного сырья, развитие инфраструктуры и логистического обеспечения, что создаст условия для роста производства продукции животноводства к уровню 2015 г. $-110,2 \%$.

Проведенные исследования позволили выявить условия и факторы внешней экономической среды функционирования отраслей животноводства Республики Беларусь. К наиболее значимым нами отнесены:

усиление конкуренции на рынке государств - членов ЕАЭС в условиях реализации комплекса мер по обеспечению продовольственной безопасности, импортозамещению и развитию экспорта;

низкий уровень цен производителей продукции животноводства, что в условиях высоких затрат не позволяет обеспечить достаточный для расширенного воспроизводства уровень эффективности отрасли;

несовершенство системы ценообразования и системы бухгалтерского учета затрат (по молочному и мясному скотоводству) в отрасли;

высокая импортная составляющая в ресурсах кормов, ветеринарных препаратов и племенного скота;

производственные мощности комбикормовой промышленности; 
высокий уровень цен на энергоносители, оказывающий влияние на себестоимость продукции;

волатильность мировых цен на продукцию животноводства, что в условиях экспортной ориентации мясного и молочного подкомплексов национального АПК определяет эффективность поставок продукции на внешний рынок;

динамика емкости внутренних рынков государств - членов ЕАЭС.

В контексте проводимой агропромышленной политики государств - членов ЕАЭС приоритетными направлениями развития животноводства Республики Беларусь являются повышение уровня производства и конкурентоспособности продукции отрасли. Это предусматривает: решение проблемы снижения импортоемкости производства мясной и молочной продукции укреплением кормовой базы на основе отечественного производства сои и продуктов ее переработки с учетом особенностей возделывания и использования данной культуры в животноводстве; реализацию совместных с государствами членами ЕАЭС межотраслевых проектов по развитию импортозамещающих производств в сфере средств защиты сельскохозяйственных животных с участием ведущих национальных научных организаций; дальнейшее развитие племенного скотоводства на основе создания информационных баз данных о геномах, внедрения генетической паспортизации сельскохозяйственных животных с высокой продуктивностью, использования инновационных технологий проведения геномной селекции и государственной поддержки производителей племенной продукции.

\section{СПИСОК ЛИТЕРАТУРЫ (REFERENCES)}

Бельский В.И. 2017. Вопросы развития сельского хозяйства Беларуси в контексте тенденций трансграничного рынка агропродовольственной продукции. Весці Нащыянальнай акадэміі навук Беларусі. № 1. С. 32-41. [Belsky V.I. 2017. Issues of agriculture development in Belarus in the context of trans-boundary market of agrofood products. Vestsi Natsyyanal'nay akademii navuk Belarusi. No 1. PP. 32-41. (In Russ.)]

Бельский В.И., Карпович Н.В. 2019. Механизм сбалансированного развития внешней торговли агропродовольственньми товарами Белару- си в рамках ЕАЭС. Минск: Институт системных исследований в АПК НАН Беларуси. [Belsky V.I., Karpovich N.V. 2019. The mechanism for the balanced development of foreign trade in agri-food products of Belarus within the framework of the EAEU. Minsk: Institut sistemnykh issledovaniy v APK NAN Belarusi. (In Russ.)]

Васильев В.В., Левкина О.В. 2017. Производство сои и соевых кормовых продуктов в Беларуси. Вестник Белорусской государственной сельскохозяйственной академии. № 4. С. 5-8. [Vasil'ev V.V., Levkina O.V. 2017. Production of soy and soy feed in Belarus. Vestnik Belorusskoy gosudarstvennoy sel'skokhozyaystvennoy akademii. No 4. PP. 5-8. (In Russ.)]

Гусаков В., Шпак А., Киреенко Н., Бычков Н., Казакевич И., Байгот Л., Пашкевич О., Бречко Я., Горбатовский А. 2017. Тенденции и направления развития АПК Республики Беларусь. Аграрная экономика. № 7. C. 2-16. [Gusakov V., Shpak A., Kireenko N., Bychkov N., Kazakevich I., Baygot L., Pashkevich O., Brechko Ya., Gorbatovskiy A. 2017. Trends and directions of agro-industrial complex development in the Republic of Belarus. Agrarnaya economika. No 7. PP. 2-16. (In Russ.)]

Гусаков В.Г., Шпак А.П., Киреенко Н.В., Кондратенко С.А. 2018. Условия и факторы реализации Доктрины национальной продовольственной безопасности Республики Беларусь до 2030 года. Весиі Наџьянальнай акадэміі навук Беларусі. Серыя аграрных навук. Т. 56. № 3. С. 263-285. [Gusakov V.G., Shpak A.P., Kireyenka N.V., Kondratenko S.A. 2018. Conditions and factors of realization of the Doctrine of National Food Security of the Republic of Belarus till 2030. Vestsi Natsyyanal'nay akademii navuk Belarusi. Seryya agrarnykh navuk. Vol. 56. No 3. PP. 263-285. (In Russ.)]

Дайнеко Е.А. 2012. Приоритеты международной экономической интеграции Республики Беларусь. Экономика Республики Беларусь в интеграционных процессах: тенденции, проблемы и перспекmuвы. C. 5-14. [Dayneko E.A. 2012. Mechanism of balanced development of foreign trade in agrifoods of Belarus within the EAEC. Ekonomika Respubliki Belarus' $v$ integracionnyh processah: tendencii, problemy $i$ perspektioy. PP. 5-14. (In Russ.)]

Догиль Л.Ф. 2018. Восприятие и идентификация рисков в аграрном бизнесе. Экономика. Моделирование. Прогнозирование. Вып. 12. С. 84-91. [Dogil L.F. 2018. Perception and Identification of Risk in Agricultural Business. Ekonomika. Modelirovaniye. Prognozirovaniye. Iss. 12. PP. 84-91. (In Russ.)]

Ильина 3.M. 2012. Глобальные проблемы и устойчивость национальной продовольственной безопасности. Минск: Институт системных исследований в АПК НАН Беларуси. [Il'ina Z.M. 2012. Global challenges and sustainability of national food security. Minsk: Institut sistemnykh issledovaniy v APK NAN Belarusi. (In Russ.)] 
Киреенко Н.В., Кузнецова А.Р. 2019. Сравнительный анализ развития сельского хозяйства Республики Беларусь и Российской Федерации. Аграрная экономика. № 1. С. 57-65. [Kireyenko N., Kuznetsova A. 2019. Comparative analysis of the development of agriculture of the Republic of Belarus and the Russian Federation. Agrarnaya economika. No 1. PP. 57-65. (In Russ.)]

Кузнецова А., Киреенко Н., Авзалов М. 2019. Тенденции развития отрасли молочного скотоводства в Российской Федерации и Республике Беларусь. Международный сельскохозяйственный журнал. № 6. С. 58-61. [Kuznetsova A., Kireenko N., Avzalov M. 2019. Development trends of the dairy cattle breederstva the Russian Federation and the Republic of Belarus. Mezhdunarodnyy sel'skokhozyaystvennyy zhurnal. No 6. PP. 58-61. (In Russ.)]

Ушачев И.Г., Папцов А.Г., Долгушкин Н.К., Серков А.Ф., Маслова В.В., Чекалин В.С. 2017. Стратегчческие направления развития сельского хозяйства России в условиях углубления интегращии в ЕАЭС. Москва: Российская академия наук. [Ushachev I.G., Papcov A.G., Dolgushkin N.K., Serkov A.F., Maslova V.V., Chekalin V.S. 2017. Strategic Directions of Agriculture Development in
Russia in Conditions of Deeper Integration into EAEC. Moscow: Rossiyskaya akademiya nauk. (In Russ.)]

Haberli C., Oliveira T., Yanaze M. 2017. Understanding the determinants of adoption of enterprise resource planning (ERP) technology within the agri-food context: the case of the Midwest of Brazil. International Food and Agribusiness Management Review. URL: https://doi.org/ 10.22434/IFAMR2016.0093

Morales L.E. 2017. The effects of international price volatility on farmer prices and marketing margins in cattle markets. International Food and Agribusiness Management Review. URL: https:// doi.org/10.22434/IFAMR2017.0020

Olthaar M., Dolfsma W., Lutz C., Noseleit F. 2019. Strategic resources and smallholder performance at the bottom of the pyramid. International Food and Agribusiness Management Review. URL: https:// doi.org/10.22434/IFAMR2018.0111

Röhrig M., Hardeweg B., Lentz W. 2018. Efficient farming options for German apple growers under risk - a stochastic dominance approach. International Food and Agribusiness Management Review. URL: https://doi.org/10.22434/IFAMR2017.0022

\title{
EXTERNAL CONDITIONS AND FACTORS FOR LIVESTOCK SECTOR OPERATIONS IN THE REPUBLIC OF BELARUS
}

\author{
Natallia Kireyenka ${ }^{1}$, Aliaksandr Gorbatovski ${ }^{2}$, Aksana Harbatouskaya ${ }^{2}$, \\ Liudmila Dounar ${ }^{2}$
Author affiliation: ${ }^{1}$ Institute for Advanced Training and Retraining of Agricultural Personnel, Belarusian State Agrarian Technical University (Minsk, Belarus);
${ }^{2}$ Institute for Systemic Research in AIC, National Academy of Sciences of Belarus (Minsk, Belarus).

Corresponding author: Natallia Kireyenka (natallia_kireenko@mail.ru).

ABSTRACT. The assessment of conditions and factors of external economic environment of functioning of the main livestock breeding sectors in the new conditions of management was made. From the point of view of import intensity and competitiveness of animal production the condition of the branch on separate kinds of its production resources, such as forages, veterinary preparations and breeding cattle is analyzed. The level of production of animal products in the member states of the Eurasian Economic Union has been determined and the competitive advantages of the animal husbandry sectors of Belarus under the conditions of the EEU functioning have been assessed by the price of commodity producers, the level of productivity of agricultural animals, profitability of production. Significant external factors determining the modern vector of livestock breeding development in the context of implementing a set of measures to ensure food security, import substitution and export development in conditions of growing competition in the market of EEU member states have been identified.

KEYWORDS: agriculture, animal husbandry, feed production, competitiveness, Eurasian Economic Union.

JEL-code: Q10, Q11, Q12, Q17, Q18.

DOI: $10.46782 / 1818-4510-2020-2-96-108$ 